\title{
Assessing the Ethos of Anglican Primary Schools in Wales: The Student Voice Project
}

\author{
Leslie J. Francis (D), David W. Lankshear (D) and Emma L. Eccles ${ }^{1}$ \\ Email: leslie.francis@warwick.ac.uk
}

(Received 8 April 2020; revised 2 September 2020; accepted 14 April 2021; first published online 17 May 2021)

\begin{abstract}
Since the Anglican Church in England and Wales began to build schools long before the state developed machinery to do so, around a quarter of all primary schools remain connected with the Anglican Church. The church school inspection system maintains that Anglican schools have a distinctive ethos. The Student Voice Project argues that school ethos is generated by the implicit collective values, beliefs and behaviours of the students, and was designed to give explicit voice to the students in response to six specific areas of school life identified by the Anglican school inspection criteria as relevant to school ethos. Drawing on data provide by 8,111 year-five and year-six students attending Church in Wales primary schools, the present study reports on the six ethos measures and on significant differences reported by female and male students, and by year-five and year-six students.
\end{abstract}

Keywords: church schools, quantitative research, school ethos, student values, student voice, Wales

\section{Introduction}

Anglican church schools remain a highly visible component of primary school provision throughout England and Wales, currently accounting for $26.1 \%$ of primary schools in England and $9.1 \%$ of primary schools in Wales, and currently providing $18.4 \%$ of primary school places in England and 7.8\% of primary school places in Wales. This discrepancy between the proportion of schools and the proportion of school places indicates that church schools tend to be smaller schools and serves as a reminder of their historical origin. The current provision of the state-maintained system of education in England and Wales arose not from an initiative by the state but from initiatives by voluntary societies founded by the Churches and inspired by denominational rivalries during the first half of the nineteenth century, including the National Society in 1811 (an Anglican initiative), the British and Foreign School Society in 1814 (largely a Free

\footnotetext{
${ }^{1}$ Leslie J. Francis is at the Centre for Education Development, Appraisal and Research, University of Warwick, UK. David W. Lankshear is at the University of Warwick, UK. Emma L. Eccles is at Bishop Grosseteste University, UK.

( $)$ The Author(s), 2021. Published by Cambridge University Press. This is an Open Access article, distributed under the terms of the Creative Commons Attribution licence (http://creativecommons.org/licenses/by/4.0/), which permits unrestricted re-use, distribution, and reproduction in any medium, provided the original work is properly cited..
} 
Church initiative), and the Catholic Poor Schools Committee in 1847 (see, further, Cruikshank, 1963; Murphy, 1971; Francis, 1987, Chadwick, 1997). When the Government first voted monies for the provision of schools in 1833, such monies were distributed through the voluntary societies to support and supplement voluntary subscriptions. The turning point of the Education Act 1870 established the mechanism through School Boards for building schools not associated with voluntary societies or denominations. This mechanism, however, was not intended to supplant voluntary initiatives but to fill gaps left by voluntary initiatives.

From 1870 onwards schools built by the voluntary initiatives of the Churches and schools built directly by the state existed side by side (Rich, 1970). While the Education Act 1902 changed the funding mechanism of both types of schools, the major changes were left to the Education Act 1944. Under pressure to reconstruct and to refinance a nationwide post-war provision of schools, the Education Act 1944 protected the place of church schools within the state-maintained provision, and did so by offering church schools a choice between two kinds of future. Voluntary aided status allowed the Churches to retain basic control over key aspects of school management (including appointing a majority of governors, appointing core staff, and determining religious education provision), but at the cost of ongoing financial liability for the buildings. Voluntary controlled status allowed the churches to pass all ongoing financial liability to the public purse, while still owning the building and having reduced control over aspects of school management (Dent, 1947). In the second decade of the twenty-first century the Churches still retain the provisions of voluntary aided schools and voluntary controlled schools (in England and in Wales) alongside further distinctive opportunities for involvement within the state-maintained sector through academies and through offering a variety of educational support and advisory services.

The nature of the Anglican Church's involvement within the state-maintained sector of schools in England and Wales has been (and remains) quite different from that of the Roman Catholic Church. The difference comes as a consequence of the Church of England being the Established Church of the realm, across both England and Wales in 1811 when the National Society came into being, although disestablished in Wales from 1920. The clearest understanding of the Church of England's involvement in the system of state-maintained schools remains in the Durham Report (1970). This report clearly distinguishes between the two distinctive objectives of the Established Church in the provision of schools. The first objective is defined as the general aim, intending to serve the nation through the provision of education for all. The second objective is defined as the domestic aim, intending to serve the children of the Church. The Durham Report (1970) argued that, while in 1811 these two aims may have been closely aligned, by the 1970s the changing nature of society had polarized them. The Durham Report recommended the wisdom of the Church of England prioritizing the general aim over the domestic aim, prioritizing service of the nation over the nurture of the children of the Church. This view was consistent with a wider view of that time that a clear divide should exist between the educational function of schools and the nurturing function of churches (see Schools Council, 1971; Hirst, 1972; Hull, 1975; British Council of Churches, 1976, 1981).

Subsequent key reports from the Church of England have maintained (implicitly or explicitly) this key distinction presented by the Durham Report 
(1970) between the general function and the domestic function of church schools, but suggested different ways of re-tuning the balance between these two functions (Waddington, 1984; Dearing Report, 2001; Chadwick, 2012; Church of England, 2016). The Church in Wales' most recent report on the church school system within the state-maintained sector drew on new independent research which demonstrated that $77 \%$ of all Church in Wales primary schools were fully committed to the general aim, while $23 \%$ also expressed some commitment to the domestic aim in their admissions policies (Lankshear, 2009).

\section{Reflecting on School Ethos}

The introduction of the concept of school ethos into educational debate is often attributed to the classic study, Fifteen Thousand Hours: Secondary Schools and their Effects on Children, by Rutter et al. (1979), as evidenced by Hargreaves (1995) and by Graham (2012). The concept of school ethos has, however, remained fragile and contested. For example, Allder (1993) speaks of the ethos of a school as 'that illusive item which is so difficult to recognise, measure, or improve' (p. 69). Donnelly (2000) argues that 'much of what we understand by school ethos is superficial and contradictory' (p. 135). In spite of such acknowledged limitations, the concept of school ethos has come to play an important part in affirming the identity and distinctiveness of church schools within the state-maintained sector of education in England and Wales and found its way securely within the inspection system appertaining to schools with a religious character following the Education (Schools) Act 1992.

The aim of the present study is to describe and to reflect on the Student Voice Project, spanning three schools years (2014-15, 2015-16 and 2016-17) designed to assess the ethos of Anglican primary schools in Wales by engaging the student voice. The context for describing and reflecting on this empirical project is shaped by three steps. Step one explores how the concept of the ethos of Anglican primary schools in Wales has been refined and embedded into the inspection system since the Education (Schools) Act 1992. Step two identifies how one specific research tradition has prioritized the student voice in exploring the lived-experience of school ethos within the church school sector. Step three introduces the Lankshear Student Voice Scales, the instrument constructed to implement the Student Voice Project.

\section{Characterizing the Ethos of Anglican Primary Schools in Wales}

The incentivization for Anglican schools in England and Wales to be explicit about the characterization of their ethos emerged as a consequence of developments in the school inspection regime. The Education (Schools) Act 1992 provided for the regular inspection of every state-maintained school in England and Wales. For voluntary schools within the state-maintained system the governors were required to ensure that those aspects of the school that had been their responsibility to oversee, with advice from the church that provided the school, were inspected on the same time scale. The provisions for the main inspection were contained in Section 9 of the Education (Schools) Act 1992 and for the 'denominational inspection of church schools' in Section 13. These two inspections became known by schools and others involved as Section 9 and Section 13 inspections. Although the School Inspections Act 
1996, being a consolidation Act, changed nothing of the content of the law, it did change the numbering of the sections. Thus, until the Education Act 2005 the denominational inspections were known as Section 23 inspections. Since the passage of the Education Act 2005 the denominational inspections have been known as Section 48 inspections in England and Section 50 inspections in Wales.

Around the time of the Education (Schools) Act 1992, a series of publications emerged from the Church of England Board of Education and the National Society focusing on the defining characteristics of Anglican schools, including work by Lankshear (1992a, 1992b, 1992c) and Duncan and Lankshear (1995). In his book, Looking for Quality in a Church School, Lankshear (1992b) proposed a framework for those wishing to identify the factors that contribute towards the ethos of an Anglican school being described and rated 'good'. This book provided an important starting point for the preparation of the National Society's inspection scheme in this area.

Before 1992 schools in England had been inspected by Her Majesty's Inspectors only rarely, by local authority inspectors if their authority chose to undertake inspection work, and, in the case of Church of England schools, only if the diocese offered this service and the governors requested it. The passage of the Education (Schools) Act 1992 led to a radical redevelopment of this rather haphazard arrangement for school inspection. Part of this redevelopment of inspection posed an important challenge to the Churches that provided schools within the statemaintained system. While the Roman Catholic Church decided to provide an inspection service for its schools at diocesan level, the Anglican Church commissioned The National Society (Church of England) for Promoting Religious Education (usually known as The National Society) to provide a national scheme for its schools. No other denomination had a sufficient stake in the system to develop a clear policy on the issue, but the Methodist Church used the Anglican scheme and framework for most of the inspections of its schools.

To support the National Society's programme of the 'denominational inspection of church schools' an initial guide to the inspection process was produced (Lankshear, 1993), followed by a more formal handbook (Brown and Lankshear, 1995). Two years later the second edition of the handbook was published (Brown and Lankshear, 1997) and a third edition was published in 2000 (Brown and Lankshear, 2000). Currently the Church of England inspection arrangements are known by the acronym SIAMS (Statutory Inspection of Anglican and Methodist Schools).

In 1999 powers concerning education provision in Wales were devolved to the Welsh Government. As a consequence, the Church in Wales has had to create its own responses to the particular needs of Church in Wales schools. This response led to the publication of The Church in Wales Education Review (Lankshear, 2009), the Church in Wales primary school religious education syllabus (Kay, 2004), and the creation of a Church in Wales adaptation of the National Society's framework for inspection. The Church in Wales arrangements are known by the acronym GWELLA (see www.churchschoolcymru.org).

\section{Assessing Anglican School Ethos}

In an earlier study, Francis and Penny (2013) argued that, although there is a great deal of point and value in debating from theologically, sociologically and 
educationally informed perspectives what the ethos of Anglican schools should be, there is also value in empirical enquiry examining what is the case in practice. While such empirical enquiry cannot be employed to establish what church schools should be like, there may nonetheless be advantages in establishing what church schools actually are like. Empirical studies concerned with what different groups of people think church schools are actually like can take a number of different forms. Research can focus on what is said about church schools in their policy documents, in their brochures, or on their websites (Wilkinson, 2019). Research can listen to what clergy and lay church members have to say about church schools (Francis et al., 2005), or to the view of church school governors (Francis and Stone, 1995), to the views of those who teach in church schools (Francis, 1986; Francis and Grindle, 2001), or to the views reflected in inspection reports (Lankshear, 1997; Brown, 1997). Francis and Penny (2013) argued, however, that the clearest voice on school ethos should be accessed by listening to the students themselves.

In their foundation study, Francis and Penny (2013) argued that it is the collective worldview of the pupils that is crucial in reflecting and shaping the ethos of schools. In order to generate insight into the ethos of Anglican secondary schools the collective worldview of 3,124 students (13-15 years of age) attending 15 Anglican schools is set alongside the collective worldview of 4,929 students attending 25 comparable schools with no religious character. The worldview of students was profiled across 10 value domains defined as Christian beliefs, church and society, non-traditional beliefs, personal aims in life, personal well-being, attitudes towards school, attitudes towards sexual morality, attitudes towards substance use, attitudes towards right and wrong, and attitudes towards the environment. Two main conclusions were drawn from these data: that the collective worldview of students attending Anglican secondary schools was not greatly different from the collective worldview of students attending comparable schools with no religious character; and that the collective worldview of students attending Anglican schools generated an ethos consistent with a predominantly secular host culture.

In two subsequent studies, Francis et al. (2018a) and Francis and Village (2020) reported on a study exploring the voices of students attending 10 Christian ethos secondary schools. In the first of these two studies, Francis et al. (2018a) argued that it is the collective worldview of the students that is crucial both in reflecting and in shaping the ethos of schools. In order to understand the potential distinctiveness of Christian ethos schools, Francis et al. (2018a) undertook two different analyses. In the first analysis they compared the collective worldview of 2,942 year-nine and year-ten students attending the 10 Christian ethos schools with the collective worldview of 13,861 students attending 71 schools without a religious character. In the second analysis they drew on the characterization of the Durham Report (1970) that distinguished between the two main objectives of the Anglican Church's involvement in state-maintained education as serving churchgoing families (the domestic aim) and as serving the local community (the general aim). Then they compared the collective worldview of 194 students attending an Anglican school that prioritized the Church's domestic function in education with the collective worldview of 302 students that prioritized the Church's general function in education as made explicit in the two schools' and mission policies. These data demonstrated that the major differences occurred not between Christian ethos schools 
and schools without a religious character, but between Anglican schools that voice their interpretation of the Church's mission in education differently.

In the second of these two studies, Francis and Village (2020) argued that assessment of student attitude toward Christianity may provide a crucial indicator of the lived-experience of Christian ethos schools. In this study, Francis and Village (2020) employed multi-level linear statistical modelling to examine the power of schoollevel and individual-level factors to predict individual differences in scores recorded on the Francis Scale of Attitude toward Christianity (Francis et al., 1995) by 6,036 students (who self-identified as either Christian or as no religion) in year-seven, year-eight, year-nine, year-ten and year-eleven classes within the 10 Christian ethos secondary schools. The data demonstrated the complex relationships between school admissions policies, parental church attendance, and the students' age and sex. Overall, parental church attendance emerged as a decisive factor in promoting a positive attitude toward Christianity among the students. Interpreting this finding, Francis and Village (2020) argued that Christian ethos secondary schools needed to make a realistic assessment of the connection between admissions policies and the formulation of ethos statements and aspirations.

\section{Introducing the Lankshear Student Voice Scales}

As part of its continuing response to the Section 50 inspection requirements the Church in Wales initiated the Student Voice Project in 2013 in order to assess the extent to which the students' experiences of their schools were consistent with the aspirations of the church concerning the distinctive school ethos of church primary schools. During the school year 2013-14 David W. Lankshear and colleagues worked alongside the Provincial Education Officer for the Church in Wales to design a set of scales constructed to map areas identified by the Section 50 inspection criteria concerning aspects of the distinctiveness of the school ethos and concerning school worship. The design and development of these scales is reported by Lankshear et al. (2017) drawing on data provided by 1,899 year-five and year-six students (9- to 11-year-olds), from church schools across Wales, who had participated in the two pilot projects conducted during the school years 2013-14 and 2014-15.

A sequence of factor analyses and reliability analyses identified, from among the 50 items included in the questionnaire, six sets of items (each set comprising five or six items) that mapped conceptually on to six areas identified by the Section 50 inspection criteria as discussed by Lankshear (1992c) in Looking for Quality in a Church School. These six areas were characterized as: attitude toward school character, attitude toward school experience, attitude toward school teachers, attitude toward relationships in school, attitude toward school and environment, and attitude toward school worship. These six scales generated alpha coefficients (Cronbach, 1951) ranging from .73 to .78, demonstrating satisfactory levels of internal consistency reliability (DeVellis, 2003). Together these six scales have been known as the Lankshear Student Voice Scales (LSVS).

In a second study, Francis et al. (2018b) tested the psychometric properties of the Lankshear Student Voice Scales proposed by Lankshear et al. (2017) among a sample of 4,581 year-four, year-five and year-six students, examining data for the 
three year groups separately. Among year-six students the alpha coefficients ranged from .73 to .80 , and among year-five students from .75 to .81 . Among year-four students the alpha coefficients ranged from .70 to .76 , confirming satisfactory performance among this younger age group. Francis et al. (2018b) also reported a consistent correlation across all six scales with sex, age, church attendance and personal prayer. Higher scores on all six scales were associated with being female, being younger, attending church and engaging in prayer.

\section{The Student Voice Project}

The Student Voice Project invited Anglican primary schools across the six dioceses of the Church in Wales to administer the Lankshear Student Voice Scales developed by Lankshear et al. (2017), together with the Francis Scale of Attitude toward Christianity (see Francis et al., 2017) and a measure of spiritual well-being (see Francis et al., 2018c), to their year-five and year-six students during the three consecutive school years, 2014-15, 2015-16 and 2016-17. The aim of the project was to provide on each of these school years profiles for the whole Province, for each participating diocese and for each participating school. The school level profiles were designed to assist governors and staff within individual schools to reflect on their students' perception of the school ethos and to draw on these data both to assist school self-reflection on strategic development, and to contribute to an evidence-based school inspection process.

On the completion of the three-year project, the aim of the present study is to review the data collected over the three-year period in order to assess the properties of the Lankshear Student Voice Scales, to map the ethos of Anglican schools in Wales as seen through the eyes of the students attending these schools, and to explore potential differences in the perception of school ethos between male and female students, and between year-five and year-six students.

\section{Method}

\section{Procedure}

All Church in Wales voluntary aided and voluntary controlled primary schools through the six dioceses in the Province (Bangor, Llandaff, Monmouth, St Asaph, St Davids, and Swansea and Brecon) were invited to administer the Student Voice Project survey to all their year-five and year-six students during the three consecutive schools years 2014-15, 2015-16 and 2016-17. Participation by the students was voluntary, anonymous and confidential. Over the three years, 118 schools participated in the project, although not all of these schools participated each year: 44 participated in 2014-15, 85 in 2015-16, and 88 in 2016-17. This response represents a high proportion $(79 \%)$ of the 150 schools eligible for participation in the project. Over the three years useable responses were received from 8,111 students.

\section{Instrument}

The Lankshear Student Voice Scales (LSVS; Lankshear et al., 2017) operationalized the Section 50 inspection criteria by five 6-item scales (assessing attitude toward 
Table 1. Scale properties

\begin{tabular}{lcccc}
\hline & N items & Alpha & Mean & SD \\
\hline School character & 6 & .75 & 26.2 & 3.3 \\
\hline School experience & 6 & .79 & 26.6 & 4.1 \\
\hline School teachers & 6 & .78 & 26.3 & 3.4 \\
\hline Relationships in school & 6 & .80 & 27.0 & 3.0 \\
\hline School and environment & 6 & .77 & 26.3 & 3.2 \\
\hline School worship & 5 & .80 & 18.5 & 4.5 \\
\hline
\end{tabular}

Note: $N=8,111$.

school character, attitude toward school experience, attitude toward school teachers, attitude toward relationships, and attitude toward school and environment), and one 5-item scale (assessing attitude toward school worship). Each item was rated on the conventional 5-point scale: disagree strongly (1), disagree (2), not certain (3), agree (4), and agree strongly (5).

\section{Participants}

Over the years 8,111 students participated in the survey: 1,899 in $2014-15 ; 3,070$ in 2015-16; and 3,142 in 2016-17. Overall, the 8,111 participants comprised 4,098 boys and 4,013 girls, 4,092 year-five students and 4,019 year-six students.

\section{Analysis}

The data were analysed by the SPSS statistical package, employing the frequency, reliability, and $t$-test routines.

\section{Results}

The first step in exploring the data was to check that the six scales were performing satisfactorily among the present sample of 8,111 year-five and year-six students. These data are presented in Table 1 in terms of the alpha coefficient (Cronbach, 1951) and the means and standard deviations. The findings are in line with earlier reports on the scale generated by Lankshear et al. (2017) and by Francis et al. (2018b), with alpha coefficients ranging between .75 and .80 .

The second step in exploring the data was to examine the students' responses to the individual items comprising the six scales. Table 2 presents these individual items together with two core statistics: the correlations between the individual items and the sum of the other items within the scale, and the percentage endorsements of the item expressed as 'yes' (sum of agree and agree strongly response), '?' (not certain), and 'no' (sum of disagree and disagree strongly responses). The correlations demonstrate how well the individual items co-vary with the other items within the set. The percentage endorsements demonstrate the overall level of response of the students across the three years in which the survey was conducted. Each of these 
Table 2. School-related attitudes: overview

\begin{tabular}{|c|c|c|c|c|}
\hline & $r$ & Yes \% & $? \%$ & No $\%$ \\
\hline \multicolumn{5}{|l|}{ Attitude toward school character } \\
\hline My school is a really good school & .56 & 91 & 7 & 2 \\
\hline My school is a really caring school & .62 & 89 & 9 & 2 \\
\hline My school treats every child fairly & .51 & 73 & 16 & 11 \\
\hline Worship is very important in my school & .38 & 90 & 9 & 1 \\
\hline My school is a really friendly school & .54 & 84 & 12 & 4 \\
\hline Prayer is very important in my school & .40 & 91 & 7 & 2 \\
\hline \multicolumn{5}{|l|}{ Attitude toward school experience } \\
\hline In my school the rules are fair & .42 & 86 & 11 & 13 \\
\hline In my school I can be myself & .47 & 70 & 17 & 13 \\
\hline My school is a peaceful place & .59 & 67 & 21 & 12 \\
\hline My school is a safe place & .62 & 86 & 10 & 4 \\
\hline My school looks good & .55 & 81 & 13 & 6 \\
\hline My school is a clean place & .58 & 78 & 15 & 7 \\
\hline \multicolumn{5}{|l|}{ Attitude toward school teachers } \\
\hline The teachers in my school care a lot for all the children & .53 & 91 & 7 & 2 \\
\hline The teachers in my school care a lot for each other & .51 & 90 & 9 & 1 \\
\hline The teachers in my school care a lot for the world around us & .52 & 89 & 10 & 1 \\
\hline The teachers in my school care a lot about the school & .51 & 93 & 6 & 1 \\
\hline When I do well in my school the teachers praise me & .58 & 79 & 14 & 7 \\
\hline When I do well in my school the grown-ups praise me & .56 & 77 & 16 & 7 \\
\hline \multicolumn{5}{|l|}{ Attitude toward relationships in school } \\
\hline My school teaches me to respect other people & .51 & 95 & 4 & 1 \\
\hline My school teaches me to respect other people's things & .50 & 95 & 4 & 1 \\
\hline My school teaches me to care for other people & .60 & 95 & 4 & 1 \\
\hline At my school we value each other & .58 & 84 & 13 & 3 \\
\hline In my school we care a lot for each other & .59 & 86 & 10 & 4 \\
\hline Caring for others is very important in my school & .61 & 95 & 4 & 1 \\
\hline \multicolumn{5}{|l|}{ Attitude toward school and environment } \\
\hline My school teaches me to respect things that grow & .52 & 83 & 14 & 3 \\
\hline My school teaches me to respect wonderful things & .53 & 88 & 10 & 2 \\
\hline My school teaches me to care for the world around us & .53 & 93 & 6 & 1 \\
\hline At my school we are proud of our school grounds & .53 & 85 & 12 & 3 \\
\hline
\end{tabular}


Table 2. (Continued)

\begin{tabular}{lccccc}
\hline & $r$ & Yes \% & ?\% & No \% \\
\hline At my school we are proud of our school buildings & .53 & 87 & 11 & 2 \\
\hline Keeping the school tidy is important in my school & .47 & 89 & 8 & 3 \\
\hline Attitude toward school worship & & & & \\
\hline I enjoy being with the whole school & .53 & 71 & 20 & 9 \\
I enjoy visits from the vicar & .63 & 65 & 22 & 13 \\
\hline Singing is important to me & .53 & 60 & 21 & 19 \\
\hline Being quiet and still is important to me & .54 & 54 & 25 & 21 \\
\hline Listening to the Bible is important to me & .66 & 56 & 24 & 20 \\
\hline
\end{tabular}

Note: Yes = sum of agree and agree strongly; ? = not certain; no = sum of disagree and disagree strongly.

six scales will be discussed briefly in light of the data presented in Table 2 in order to describe how students perceived the ethos of their Anglican school.

The scale concerned with attitude toward school character found that nine out of every ten students agreed that their school is a really good school (91\%), that prayer is very important in their school (91\%), that worship is very important in their school (90\%), and that their school is a really caring school (89\%). The proportions, however, dropped to $84 \%$ who agreed that their school is a really friendly school and to $73 \%$ who agree that their school treats every child fairly.

The scale concerned with attitude toward school experience found that eight out of every ten students agreed that in their school the rules are fair (86\%), that their school is a safe place (86\%) and that their school looks good (81\%). The proportions, however, dropped to $78 \%$ who agreed that their school is a clean place, to $70 \%$ who agreed that in their school they can be themselves, and to $67 \%$ who agreed that their school is a peaceful place.

The scale concerned with attitude toward school teachers found that nine out of every ten students agreed that the teachers in their school care a lot about the school (93\%), that the teachers in their school care a lot for all the children (91\%), that the teachers in their school care a lot for each other $(90 \%)$, and that the teachers in their school care a lot for the world around us (89\%). The proportions, however, dropped to $79 \%$ who agreed that when they do well in their school their teachers praise them, and to $77 \%$ who agreed that when they do well in their school the grown-ups praise them.

The scale concerned with attitude toward relationships in school found that nine out of every ten students agreed that their school teaches them to respect other people (95\%), that their school teaches them to respect other people's things (95\%), that their school teaches them to care for other people (95\%), and that caring for others is very important in their school (95\%). The proportions, however, dropped to $86 \%$ who agreed that in their school we care a lot for each other, and to $84 \%$ who agreed that at their school we value each other. 
Table 3. Mean scale scores by sex

\begin{tabular}{|c|c|c|c|c|c|c|}
\hline & \multicolumn{2}{|c|}{ Male } & \multicolumn{2}{|c|}{ Female } & \multirow[b]{2}{*}{$t$} & \multirow[b]{2}{*}{$p<$} \\
\hline & Mean & SD & Mean & SD & & \\
\hline School character & 25.8 & 3.5 & 26.6 & 3.1 & 9.9 & .001 \\
\hline School experience & 24.2 & 4.3 & 25.1 & 3.8 & 10.9 & .001 \\
\hline School teachers & 26.1 & 3.5 & 26.5 & 3.2 & 5.5 & .001 \\
\hline Relationships in school & 26.8 & 3.1 & 27.3 & 2.9 & 6.9 & .001 \\
\hline School and environment & 26.1 & 3.3 & 26.5 & 3.1 & 6.0 & .001 \\
\hline School worship & 17.8 & 4.7 & 19.1 & 4.1 & 13.0 & .001 \\
\hline
\end{tabular}

Note: $N=8,111$.

The scale concerned with attitude toward school and environment found that nine out of every ten students agreed that their school teaches them to care for the world around them (93\%), and that keeping the school tidy is important in their school (89\%). The proportions, however, dropped to $88 \%$ who agreed that their school teaches them to respect wonderful things, to $87 \%$ who agreed that at their school they are proud of the school buildings, to $85 \%$ who agreed that at their school they are proud of the school grounds, and to $83 \%$ who agreed that their school teaches them to respect things that grow.

The scale concerned with attitude toward school worship found that item endorsement was lower in this area than in the other five areas. Here the statistics demonstrated that $71 \%$ of the students enjoyed being with the whole school, $65 \%$ enjoyed visits from the vicar, $60 \%$ agreed that singing is important to them, $56 \%$ agreed that listening to the Bible is important to them, and 54\% agreed that being quiet and still is important to them.

The third step in exploring the data was to examine the differences in the overall mean scale scores recorded by female students and by male students. These data, presented in Table 3, demonstrate that on all six scales female students recorded significantly higher scores than male students. Table 4 illustrates the implications of these significant differences between mean scale scores in terms of the individual scale items.

In terms of attitude toward school character, $94 \%$ of female students rated their school as a really good school, compared with $88 \%$ of male students; $92 \%$ of female students rated prayers as really important in their school, compared with $89 \%$ of male students. In terms of attitude toward school experience, 90\% of female students rated their school as a safe place, compared with $83 \%$ of male students; $81 \%$ of female students rated their school as a clean place, compared with $76 \%$ of male students. In terms of attitude toward school teachers, $92 \%$ of female students rated the teachers in their school as caring a lot for all the children, compared with $89 \%$ of male students; $81 \%$ of female students agreed that when they do well in school the teachers praise them, compared with $77 \%$ of male students. In terms of attitude toward relationships in school, $96 \%$ of female students agreed that caring for others is very important in their school, compared with $93 \%$ of male students; $96 \%$ of 
Table 4. School-related attitudes by sex

\begin{tabular}{|c|c|c|}
\hline & Male \% & Female $\%$ \\
\hline \multicolumn{3}{|l|}{ Attitude toward school character } \\
\hline My school is a really good school & 88 & 94 \\
\hline My school is a really caring school & 87 & 91 \\
\hline My school treats every child fairly & 70 & 76 \\
\hline Worship is very important in my school & 89 & 91 \\
\hline My school is a really friendly school & 82 & 87 \\
\hline Prayer is very important in my school & 89 & 92 \\
\hline \multicolumn{3}{|l|}{ Attitude toward school experience } \\
\hline In my school the rules are fair & 83 & 89 \\
\hline In my school I can be myself & 68 & 73 \\
\hline My school is a peaceful place & 66 & 69 \\
\hline My school is a safe place & 83 & 90 \\
\hline My school looks good & 78 & 84 \\
\hline My school is a clean place & 76 & 81 \\
\hline \multicolumn{3}{|l|}{ Attitude toward school teachers } \\
\hline The teachers in my school care a lot for all the children & 89 & 92 \\
\hline The teachers in my school care a lot for each other & 89 & 91 \\
\hline The teachers in my school care a lot for the world around us & 88 & 90 \\
\hline The teachers in my school care a lot about the school & 93 & 94 \\
\hline When I do well in my school the teachers praise me & 77 & 81 \\
\hline When I do well in my school the grown-ups praise me & 75 & 78 \\
\hline \multicolumn{3}{|l|}{ Attitude toward relationships in school } \\
\hline My school teaches me to respect other people & 94 & 96 \\
\hline My school teaches me to respect other people's things & 94 & 95 \\
\hline My school teaches me to care for other people & 94 & 96 \\
\hline At my school we value each other & 83 & 85 \\
\hline In my school we care a lot for each other & 85 & 88 \\
\hline Caring for others is very important in my school & 93 & 96 \\
\hline \multicolumn{3}{|l|}{ Attitude toward school and environment } \\
\hline My school teaches me to respect things that grow & 82 & 85 \\
\hline My school teaches me to respect wonderful things & 86 & 90 \\
\hline My school teaches me to care for the world around us & 92 & 94 \\
\hline At my school we are proud of our school grounds & 84 & 86 \\
\hline
\end{tabular}


Table 4. (Continued)

\begin{tabular}{|c|c|c|}
\hline & Male \% & Female $\%$ \\
\hline At my school we are proud of our school buildings & 85 & 89 \\
\hline Keeping the school tidy is important in my school & 88 & 90 \\
\hline \multicolumn{3}{|l|}{ Attitude toward school worship } \\
\hline I enjoy being with the whole school & 68 & 73 \\
\hline I enjoy visits from the vicar & 63 & 67 \\
\hline Singing is important to me & 49 & 71 \\
\hline Being quiet and still is important to me & 52 & 57 \\
\hline Listening to the Bible is important to me & 54 & 57 \\
\hline
\end{tabular}

Table 5. Mean attitude scores by school year

\begin{tabular}{|c|c|c|c|c|c|c|}
\hline & \multicolumn{2}{|c|}{ Year 5} & \multicolumn{2}{|c|}{ Year 6} & \multirow[b]{2}{*}{$t$} & \multirow[b]{2}{*}{$p<$} \\
\hline & Mean & SD & Mean & SD & & \\
\hline School character & 26.4 & 3.3 & 26.0 & 3.4 & 6.8 & .001 \\
\hline School experience & 24.8 & 4.1 & 24.5 & 4.1 & 3.3 & .001 \\
\hline School teachers & 26.5 & 3.3 & 26.0 & 3.4 & 6.8 & .001 \\
\hline Relationships in school & 27.2 & 3.0 & 26.8 & 3.1 & 5.9 & .001 \\
\hline School and environment & 26.5 & 3.2 & 26.1 & 3.3 & 6.0 & .001 \\
\hline School worship & 18.9 & 4.5 & 18.0 & 4.4 & 9.3 & .001 \\
\hline
\end{tabular}

female students agreed that their school teaches them to care for other people, compared with $94 \%$ of male students. In terms of attitude toward school and environment, $89 \%$ of female students were proud of their school buildings, compared with $85 \%$ of male students; $85 \%$ of female students considered that their school teaches them to respect things that grow, compared with $82 \%$ of male students. In terms of attitude toward school worship, $71 \%$ of female students considered singing was important to them, compared with $49 \%$ of male students; $67 \%$ of female students enjoyed visits from the vicar compared with $63 \%$ of male students.

The fourth step in exploring the data was to examine the difference in the overall mean scale scores recorded by year-five and year-six students. The data presented in Table 5 demonstrate that on all six scales year-six students recorded significantly lower scores than year-five students. Table 6 illustrates the implications of these significant differences between mean scale scores in terms of the individual scale items.

In terms of attitude toward school character the main drop in endorsement between year five and year six concerned the item, 'My school treats every child fairly', from $76 \%$ to $70 \%$. In terms of attitude towards school experience, the main drop in endorsement between year five and year six concerned the item, 'In my school the rules are fair', from $88 \%$ to $84 \%$. In terms of attitude toward school 
Table 6. School-related attitudes by school year

Year $5 \%$

Year $6 \%$

Attitude toward school character

My school is a really good school 91

My school is a really caring school

My school treats every child fairly

76

Worship is very important in my school

91

My school is a really friendly school

84

Prayer is very important in my school

92

Attitude toward school experience

In my school the rules are fair

In my school I can be myself

My school is a peaceful place

My school is a safe place

My school looks good

87

My school is a clean place

81

Attitude toward school teachers

The teachers in my school care a lot for all the children

The teachers in my school care a lot for each other 91

The teachers in my school care a lot for the world around us 91

The teachers in my school care a lot about the school 91

When I do well in my school the teachers praise me 94

When I do well in my school the grown-ups praise me 79

Attitude toward relationships in school

My school teaches me to respect other people 95

My school teaches me to respect other people's things 95 95

My school teaches me to care for other people 94

At my school we value each other 95

In my school we care a lot for each other

Caring for others is very important in my school

Attitude toward school and environment

My school teaches me to respect things that grow

My school teaches me to respect wonderful things

95

My school teaches me to care for the world around us

At my school we are proud of our school grounds

At my school we are proud of our school buildings 85 82

89
87 94 93 
Table 6. (Continued)

\begin{tabular}{lcc}
\hline & Year $5 \%$ & Year $6 \%$ \\
\hline Keeping the school tidy is important in my school & 89 & 89 \\
\hline Attitude toward school worship & 72 & 70 \\
\hline I enjoy being with the whole school & 68 & 61 \\
I enjoy visits from the vicar & 63 & 58 \\
\hline Singing is important to me & 57 & 52 \\
\hline Being quiet and still is important to me & 60 & 51 \\
\hline Listening to the Bible is important to me
\end{tabular}

teachers, the main drop in endorsement between year five and year six concerned the item, 'The teachers in my school care a lot for the world around us', from $91 \%$ to $87 \%$. In terms of attitude toward relationships in school, the main drop in endorsement between year five and year six concerned the item, 'At my school we value each other' from $85 \%$ to $83 \%$. In terms of attitude toward school and environment, the main drop in endorsement between year five and year six concerned the item, 'My school teaches me to respect things that grow', from $85 \%$ to $82 \%$. In terms of attitude toward school worship, the main drop in endorsement between year five and year six concerned the item, 'Listening to the Bible is important to me', from $60 \%$ to $51 \%$.

\section{Conclusion}

The aim of the present study was to draw together the data provided by the 8,111 students who participated in the Student Voice Project, to assess the Lankshear Student Voice Scales, to map the ethos of Anglican schools in Wales as seen through the eyes of the students attending these schools, and to explore the potential differences between the perceptions of female students and male students, and between the perceptions of year-five students and year-six students. Five main conclusions emerge from the findings generated by this study.

The first conclusion concerns the Lankshear Student Voice Scales. These scales demonstrated good criteria of internal consistency reliability, both in terms of the alpha coefficients and in terms of the correlations between the individual scale items and the sum of the other items in the scale, and were sensitive to and useful in identifying significant patterns between male students and female students, and between year-five students and year-six students. On these grounds the Lankshear Student Voice Scales can be commended for further use.

The second conclusion concerns the claims that can be made about the ethos of Church in Wales primary schools on the basis of the data generated by the Lankshear Student Voice Scales. Data of this nature allows the Church in Wales to move beyond aspirational statements about the kind of ethos it would like its schools to reflect to descriptive statements about the lived-experience of the students and how they perceive the ethos of the school that they attend. These data would allow the Church in Wales to make the following kinds of claims: 
Nine out of every ten year-five and year-six students attending Church in Wales primary schools perceive their schools as a really good school, where worship and prayer are important, where the teachers care a lot about the school and about the students, where the school teaches respect for individuals, and where caring for others and for the world around us is really important.

The third conclusion is that the student voice not only affirms some of the aspirations regarding school ethos identified in the inspection process, but also draws attention to other aspirations that are not being so readily recognized by the students. Items endorsed by fewer than four-fifths of the students may invite further reflection. Fewer than four-fifths of the students affirmed that: their school treats every child fairly; in their school they can be themselves; their school is a peaceful place; their school is a clean place; and when they do well in their school their teachers praise them. Fewer than four-fifths of the students affirmed any of the five items concerned with attitude toward school worship. Further reflection on these items may result in Anglican schools agreeing that such issues are not really core to their school ethos, or in Anglican schools exploring how students' perceptions may be enhanced in such areas.

The fourth conclusion is that the student voice draws attention to ways in which the lived-experience of school life and the perception of school ethos are reported differently by male students and by female students. Specifically in terms of the present survey, a more positive attitude toward the ethos of Anglican primary schools in Wales is reported by female students, and this difference emerges with greatest clarity in relation to the explicitly religious aspects of the schools (including school worship). This finding is consistent with the more widely reported tendency for women to be more favourably disposed to the Christian tradition than men (see Francis and Penny, 2014). In discussing school ethos church schools may be wise to keep this sex difference in mind.

The fifth conclusion is that the student voice draws attention to ways in which the lived-experience of school life and the perceptions of school ethos are reported differently by year-five and year-six students. Specifically, in terms of the present survey there was a significantly less positive attitude toward the explicitly religious aspects of the school reported by year-six students than by year-five students (including school worship). This finding is consistent with the more widely reported tendency for decline in attitude toward Christianity during the years of childhood adolescence (see Kay and Francis, 1996). In discussing school ethos church schools may be wise to keep this age trend in mind.

The limitations with the present study include the reliance on a small set of five 6-item scales and one 5-item scale to operationalize the notion of Anglican school ethos as reflected in the Section 50 inspection criteria, and the restriction of the Student Voice Project to one Province of the Anglican Church. The findings from the research should, nonetheless, be strong enough to encourage further research in other Anglican Provinces with the opportunity to build on the Lankshear Student Voice Scales and possibly extend their reach to assess other identified aspects of school ethos. 


\section{References}

Allder, M. 1993 'The Meaning of "School Ethos", Westminster Studies in Education 16: 59-69. doi.org/10. 1080/0140672930160109

British Council of Churches 1976 The Child in the Church (London: British Council of Churches).

British Council of Churches 1981 Understanding Christian Nurture (London: British Council of Churches).

Brown, A.S. 1997 The Multi-faith Church School (London: The National Society).

Brown, A.S., and Lankshear, D.W. 1995 Inspection Handbook (London: The National Society).

Brown, A.S., and Lankshear, D.W. 1997 Inspection Handbook (London: The National Society, 2nd edn).

Brown, A.S., and Lankshear, D.W. 2000 Inspection Handbook (London: The National Society, 3rd edn).

Chadwick, P. 1997 Shifting Alliances: Church and State in English Education (London: Cassell).

Chadwick, P. 2012 The Church School of the Future (London: National Society).

Church of England 2016 Church of England Vision for Education: Deeply Christian, Serving the Common Good (London: Church of England).

Cronbach, L.J. 1951 'Coefficient Alpha and the Internal Structure of Tests', Psychometrika 16: 297-334. doi. org/10.1007/BF02310555

Cruickshank, M. 1963 Church and State in English Education (London: Macmillan).

Dearing Report 2001 The Way Ahead: Church of England Schools in the New Millennium (London: Church House Publishing).

Dent, H.J. 1947 The Education Act 1944: Provisions, Possibilities and Some Problems (London: University of London Press, 3rd edn).

DeVellis, R.F. 2003 Scale Development: Theory and Applications (London: Sage).

Donnelly, C. 2000 'In Pursuit of School Ethos', British Journal of Educational Studies, 48: 134-54. doi.org/ 10.1111/1467-8527.t01-1-00138

Duncan, G., and Lankshear, D.W. 1995 Church Schools: A Guide for Governors (London: The National Society).

Durham Report 1970 The Fourth R: The Report of the Commission on Religious Education in Schools (London: National Society and SPCK).

Francis, L.J. 1986 Partnership in Rural Education: Church Schools and Teacher Attitudes (London: Collins Liturgical Publications).

Francis, L.J. 1987 Religion in the Primary School: Partnership between Church and State? (London: Collins Liturgical Publications).

Francis, L.J., and Grindle, Z. 2001 'The Changing Ethos of Church Schools: A Survey of Teacher Attitudes in 1982 and 1996', Research in Education, 65: 1-19. doi.org/10.7227/RIE.65.1

Francis, L.J., and Penny, G. 2013 'The Ethos of Anglican Secondary Schools Reflected through Pupil Values: An Empirical Enquiry among 13- to 15- year-olds', in H. Worsley (ed.), Anglican Church School Education: Moving beyond the First Two Hundred Years (London: Continuum): 131-48.

Francis, L.J., and Penny, G. 2014 'Gender Differences in Religion', in V. Saroglou (ed.), Religion, Personality and Social Behaviour (New York: Psychology Press): 313-37.

Francis, L.J., and Stone, E.A. 1995 'School Governors and the Religious Ethos of Church of England Voluntary Aided Primary Schools', Educational Management and Administration 23: 176-87. doi. org/10.1177/0263211X9502300305

Francis, L. J., and Village, A. 2020 'Christian Ethos Secondary Schools, Parental Church Attendance and Student Attitude toward Christianity. Exploring Connections in England and Wales', British Journal of Religious Education, 42(3): 298-312. doi.org/10.1080/01416200.2019.1580562

Francis, L.J., Casson, A., and McKenna, U. 2018a 'Christian Ethos Secondary Schools in England and Wales: A Common Voice or Wide Diversity?' Journal of Beliefs and Values, 39: 445-62. doi.org/10. 1080/13617672.2018.1491262

Francis, L.J., Lankshear, D.W., and Eccles, E.L. 2017 'The Internal Consistency Reliability and Construct Validity of the Francis Scale of Attitude toward Christianity among 8- to 11-year-old Students in Wales', Mental Health, Religion and Culture 20: 922-929. doi.org/10.1080/13674676.2017.1315656

Francis, L.J., Lankshear, D.W., and Eccles, E.L. 2018b 'How Students Perceive Attending Church in Wales Primary Schools: A Psychometric Assessment of Section 50 Inspection Criteria', Research in Education 102: 2-12. doi.org/10.1177/0034523717740150 
Francis, L.J., Robbins, M., and Astley, J. 2005 Fragmented Faith? Exposing the Fault-lines in the Church of England (Carlisle: Paternoster).

Francis, L.J., Fisher, J.W., Lankshear, D.W., and Eccles, E.L. 2018c 'Modelling the Effect of Worship Attendance and Personal Prayer on Spiritual Wellbeing among 9- to 11-year-old students attending Anglican Church Schools in Wales', International Journal of Children's Spirituality, 23: 30-44. doi. org/10.1080/1364436X.2017.1419938

Francis, L.J., Lewis, J.M., Philipchalk, R., Brown, L.B., and Lester, D. 1995 'The Internal Consistency Reliability and Construct Validity of the Francis Scale of Attitude toward Christianity (Adult) among Undergraduate Students in the UK, USA, Australia and Canada', Personality and Individual Differences 19: 949-53. doi.org/10.1016/S0191-8869(95)00131-X

Graham, A. 2012 'Revisiting School Ethos: The Student Voice', School Leadership and Management 32: 341-54. doi.org/10.1080/13632434.2012.708330

Hargreaves, D.H. 1995 'School Culture, School Effectiveness and School Improvement', School Effectiveness and School Improvement 6: 23-46. doi.org/10.1080/0924345950060102

Hirst, P.H. 1972 'Christian Education: A Contradiction in Terms?', Learning for Living 11: 6-11. doi.org/10. 1080/00239707208556777

Hull, J.M. 1975 School Worship: An Obituary (London: SCM).

Kay, W.K. 2004 Religious Education Syllabus for Primary Schools (Cardiff: Church in Wales).

Kay, W.K., and Francis, L.J. 1996 Drift from the Churches: Attitude toward Christianity during Childhood and Adolescence (Cardiff: University of Wales Press).

Lankshear, D.W. 1992a A Shared Vision: Education in Church Schools (London: The National Society).

Lankshear, D.W. 1992b Looking for Quality in a Church School (London: The National Society).

Lankshear, D.W. 1992c Governing Church Schools (London: The National Society).

Lankshear, D.W. 1993 Preparing for Inspection in a Church School (London: The National Society).

Lankshear, D.W. 2009 The Church in Wales Education Review (Cardiff: Church in Wales).

Lankshear, D.W., Francis, L.J., and Eccles, E.L. 2017 'Engaging the Student Voice in Dialogue with Section 50 Inspection Criteria in Church in Wales Primary Schools: A Study in Psychometric Assessment', Journal of Research on Christian Education 26: 237-50. doi.org/10.1080/10656219.2017.1384693

Lankshear, J.F. 1997 Denominational Inspection in Primary Schools (London: The National Society).

Murphy, J. 1971 Church, State and Schools in Britain 1800-1970 (London: Routledge and Kegan Paul).

Rich, E.E. 1970 The Education Act 1870 (London: Longmans).

Rutter, M., Maughan, B., Mortimore, P., Ouston, J., and Smith, A. 1979 Fifteen Thousand Hours: Secondary Schools and their Effects on Children (London: Open Books).

Schools Council 1971 Religious Education in Secondary Schools (London: Evans Brothers and Methuen).

Waddington, R. 1984 A Future in Partnership (London: The National Society).

Wilkinson, J. 2019 'The Rural and Small Church of Ireland Primary School: The Use of School Websites to Define School Ethos', Rural Theology 17: 72-84. doi.org/10.1080/14704994.2019.1649822

Cite this article: Francis, L.J., Lankshear, D.W., and Eccles, E.L. (2021). Assessing the Ethos of Anglican Primary Schools in Wales: The Student Voice Project. Journal of Anglican Studies 20, 80-97. https:// doi.org/10.1017/S1740355321000085 